\title{
Impact of Pandan Leaf Extract Addition on the Oxidative Degradation of Sunflower Oil during Microwave Heating
}

\author{
(Kesan Penambahan Ekstrak Daun Pandan pada Pencemaran Oksidatif Minyak Bunga Matahari \\ semasa Pemanasan Ketuhar Gelombang Mikro)
}

\author{
M. AbBas Ali*, RAFIQQAH Binti MOHAMAd SABRI, KHU SAY Li \& NiK AZMi NiK MAHMOOD
}

\begin{abstract}
The efficacy of pandan leaf extract (PLE) addition on the oxidative degradation of sunflower oil (SFO) during microwave heating was studied. $80 \%$ of methanol extract showed better antioxidant action than the $100 \%$ methanol or ethanol extract and the total phenolic contents, DPPH radical scavenging activity and linoleic acid system of PLE were found to be $1845.50 \mathrm{mg} \mathrm{GAE} / 100 \mathrm{~g}, 60.62-89.87 \%$ and $82.21 \%$, respectively. $80 \%$ of methanolic extracts at different concentrations $(0.1,0.2$ and $0.4 \mathrm{wt} . \%)$ were added to SFO. The antioxidant treated and control oil samples were subjected to microwave heating and were analyzed at regular intervals for the extent of oxidative changes following the measurements of peroxide value, p-anisidine value, TOTOX, free fatty acid, specific extinction, iodine value, viscosity, polar compounds and fatty acid composition. The PLE were found to be quite effective towards suppressing the primary and secondary oxidation products in the tested oil. The order of effectiveness $(\mathrm{p}<0.05)$ was BHA $>0.4 \%$ PLE $>0.2 \%$ PLE $>0.1 \%$ PLE $>$ control. The present results suggested that antioxidant extract from pandan leaf might be used to protect vegetable oils from oxidation.
\end{abstract}

Keywords: Antioxidants; fatty acids; microwave heating; oxidative stability; sunflower oil

\section{ABSTRAK}

Keberkesanan penambahan ekstrak (PLE) daun pandan pada pencemaran oksidatif minyak bunga matahari (SFO) dalam ketuhar gelombang mikro dikaji. 80\% ekstrak metanol menunjukkan tindakan antioksidan yang lebih baik daripada 100\% metanol atau ekstrak etanol, jumlah kandungan fenolik, aktiviti skavengan radikal DPPH dan sistem asid linoleik PLE yang masing-masing ialah $1845.50 \mathrm{mg}$ GAE/100 g, 60.6-89.87\% dan 82.21\%.80\% ekstrak metanolik pada kepekatan berbeza (0.1, 0.2 dan 0.4 wt. \%) telah ditambah ke SFO. Sampel minyak terawat antioksidan dan kawalan melalui pemanasan ketuhar gelombang mikro dianalisis pada selang yang tetap untuk tahap perubahan oksidatif berikutan pengukuran nilai peroksida, nilai p-anisidine, TOTOX, asid bebas lemak, kepupusan tertentu, nilai iodin, kelikatan, sebatian kutub dan komposisi asid lemak. PLE didapati berkesan dalam menahan pengoksidaan primer dan sekunder dalam minyak yang diuji. Tahap keberkesanan $(\mathrm{p}<0.05)$ adalah BHA $>0.4 \%$ PLE $>0.2 \%$ PLE $>0.1 \%$ PLE $>$ kawalan. Keputusan kajian mencadangkan bahawa ekstrak antioksidan daripada daun pandan boleh digunakan untuk melindungi minyak sayuran daripada pengoksidaan.

Kata kunci: Antioksidan; asid lemak; kestabilan oksidatif; minyak bunga matahari; pemanasan ketuhar gelombang mikro

\section{INTRODUCTION}

For preparing food microwave heating is one of the most attractive cooking methods, commonly employed in households and especially in restaurants for its high speed, convenience and efficiency compared to conventional heating method. In vegetable oils exposed to microwave energy, the higher the amount of polyunsaturated fatty acids (PUFAs) in the oils, the greater is the rate of quality deterioration of the oils (Yoshida et al. 1992). In the quality deterioration of vegetable oils, fats and other food systems lipid peroxidation is mainly responsible that results in the losses of nutritional value of food, changes in color, texture, sensory and other physiological properties (Che Man \& Tan 1999). Due to these changes, consumers do not want to take oxidized products and food industries suffer from economic losses. The oil industry has to give special attention in this context, as oils, fats and fatty foods suffer stability problems (Wu \& Nawar 1986). The oils containing high amount of unsaturated fatty acids (USFAs), especially PUFA, are more susceptible to oxidation. SFO is one of the most popular vegetable oils and in some countries it is preferred to soybean, cottonseed and palm oils. It contains high amount of vitamin $\mathrm{E}$ with alpha-tocopherol and linoleic acid (Huang et al. 1981). High reactivity of these USFAs is associated with oxidation, loss of nutritional value and quality (Labuza 1971). To avoid or delay lipid oxidation during food processing, different types of antioxidants are being used to protect the oil from oxidation when exposed to high temperature. The addition of synthetic antioxidants in lipid containing foods is often discouraged due to their safety and perceived carcinogenicity. On the other hand, the addition of plant-based antioxidants to 
foods and preventive medicine are gaining a great deal of interest because of their potential health benefits (Hussain et al. 2008). The leaves of Pandanus amaryllifolius Linn., known as pandan, are commonly used to give a refreshing, fragrant flavor to south-east Asian dishes (Bhattacharjee et al. 2005). Besides its culinary value, pandan leaves are also used in the perfume industry and also medicinally as a diuretic, cardio-tonic and anti-diabetic (Wakte et al. 2010). Jimtaisong and Krisdaphong (2013) stated that PLE is a potential natural antioxidant, which can serve as an alternative to synthetic antioxidants in topically applied formulations.

Very few research work on antioxidant effectiveness of plant sources on quality and oxidative stability of vegetable oils during microwave heating has been previously studied (Malheiro et al. 2012; Ricardo et al. 2013; Rodrigues et al. 2012). To the best of our knowledge, nothing has been reported on the antioxidant action of PLE in SFO oxidation during microwave heating. Therefore, the present work was aimed to investigate the effect of PLE addition on the oxidative degradation of sunflower oil during microwave heating.

\section{MATERIALS AND METHODS}

Refined sunflower oil (Lam Soon Edible Oils Sdn. Bhd., Selangor, Malaysia) and pandan leaves were purchased from local market (Johor, Malaysia). Chemicals and solvents used were of analytical grade. $p$-anisidine and silica gel were products of Merck (Darmstadt, Germany). Standards of fatty acid methyl esters were procured from Supelco Chemical Co. (Bellefonte, PA, USA). All other chemicals and solvents were from J.T. Baker (Phillipsburg, USA) or RCI Labscan Ltd. (Pathumwan, Thailand) unless otherwise stated.

\section{PREPARATION OF PANDAN LEAF EXTRACT}

Pandan leaves were cleaned, sundried and again dried in an electric oven at $45^{\circ} \mathrm{C}$ for $24 \mathrm{~h}$ and ground to fine powder. About $50 \mathrm{~g}$ of powdered material were extracted with $500 \mathrm{~mL}$ of methanol in a shaking incubator (SASTEC Model ST-250D, Selangor, Malaysia) at room temperature overnight at a speed of $250 \mathrm{rpm}$. The extract was filtered and residue was re-extracted with $400 \mathrm{~mL}$ of solvent. This procedure was repeated to ensure the complete extraction of phenolic compounds and the combined filtrates were subjected to rotary evaporation (Buchi Rotavapor R-114, Flawil, Switzerland) at $45^{\circ} \mathrm{C}$ under reduced pressure for removal of solvent. The same process was followed for the extraction with ethanol and $80 \%$ methanol in water. The extracts were weighed to calculate the yield and stored at $-4^{\circ} \mathrm{C}$ prior to further analyses.

\section{DPPH SCAVENGING ASSAY AND TOTAL PHENOLIC ASSAY}

The radical scavenging power was determined by the 2,2-diphenyl-1-picrylhydrazyl (DPPH) method and the results were expressed as the percentage inhibition of the reduction of DPPH radicals in methanol (Blois 1958). $4 \mathrm{~mL}$ of DPPH in methanol $(0.1 \mathrm{mmol} / \mathrm{L})$ was added to $1 \mathrm{~mL}$ of the leaf extract solution at 500, 1000 and 1500 ppm. After 20 min being kept in the dark, the absorbance was measured at $517 \mathrm{~nm}$ using a spectrophotometer (Lambda 25, Perkin Elmer., PerkinElmer Inc, MA, USA). Total phenolic (TP) content was determined by Folin-Ciocalteu method and the results were expressed as mg of gallic acid equivalent (Lister \& Wilson 2001). Aqueous Folin-Ciocalteu reagent (1:10) was added to the plant extract or standard, incubated for $1 \mathrm{~min}$ before addition of $60 \mathrm{~g} / \mathrm{L} \mathrm{Na}_{2} \mathrm{CO}_{3}$ solution. After a 90 min incubation period, absorbance was read at $725 \mathrm{~nm}$ using same spectrophotometer as stated earlier.

\section{ANTIOXIDANT ACTIVITY IN LINOLEIC ACID SYSTEM}

The antioxidant activity of the extracts was determined by measuring the inhibition of linoleic acid peroxidation according to a method described by Kikuzaki and Nakatani (1993). In brief, $250 \mu \mathrm{g}$ extract of the sample in $0.5 \mathrm{~mL}$ of absolute ethanol were added to a mixture of $0.5 \mathrm{~mL}$ of $2.5 \%$ linoleic acid in absolute ethanol, $1 \mathrm{~mL}$ of $0.05 \mathrm{M}$ phosphate buffer $(\mathrm{pH}=7)$ and $0.5 \mathrm{~mL}$ of distilled water. The reaction mixture was incubated at $40^{\circ} \mathrm{C}$ and aliquot of $0.1 \mathrm{~mL}$ was sampled at every $12 \mathrm{~h}$ during incubation. State of oxidation was measured by sequentially adding ethanol $(9.7 \mathrm{~mL}$, $75 \%)$, ammonium thiocyanate $(0.1 \mathrm{~mL}, 30 \%)$ and ferrous chloride $(0.1 \mathrm{~mL}, 0.02 \mathrm{M}$ in $3.5 \% \mathrm{HCl})$. The mixture was incubated for $3 \mathrm{~min}$ and absorbance measured at $500 \mathrm{~nm}$ until it reached the maximum. Butylated hydroxyanisole (BHA) was used as positive control. The antioxidant activity was calculated as percentage of inhibition relative to the control using the following equation: AA $(\%)=100-$ (sample absorbance at $48 \mathrm{~h}$ - sample absorbance at $0 \mathrm{~h}$ )/ (control absorbance at $48 \mathrm{~h}-$ control absorbance at $0 \mathrm{~h}$ ) $\times 100$.

\section{MICROWAVE HEATING OPERATION}

The extract ( $80 \%$ methanol in water) which displayed highest antioxidant activity, was used in microwave treatment for stabilizing sunflower oil. The treatments were: Sunflower oil containing $0.1 \%$ leaf extract $\left(\mathrm{SFP}_{1}\right)$; Sunflower oil containing $0.2 \%$ leaf extract $\left(\mathrm{SFP}_{2}\right)$; Sunflower oil containing $0.4 \%$ leaf extract $\left(\mathrm{SFP}_{4}\right)$; Sunflower oil containing $0.02 \%$ BHA (SFB); and Sunflower oil without any additive (SFO) as control. The concentrations of leaf extracts were calculated as weight percent. The sunflower oil was heated to $50^{\circ} \mathrm{C}$ before adding extract and stirred until completely dissolved. The oil samples $(80 \mathrm{~mL})$ were put into $100 \mathrm{~mL}$ glass bottles which were placed at equal distances on the turntable plate of a domestic microwave oven (Model NN-ST342M, Panasonic Co.Ltd., China). The samples were then heated for various periods $(0,4,8,16,24 \mathrm{~min})$ at medium power setting. The final oil temperature at various heating times was measured by inserting a calibrated thermocouple 
(Model HI 9043, Hanna Instruments Ltd Bedfordshire, UK) into samples immediately after removal from the oven. All the samples were stored at $-16^{\circ} \mathrm{C}$ for further analyses.

\section{STANDARD PHYSICOCHEMICAL PROPERTIES}

American Oil Chemists' Society official methods (AOCS 1987) were employed for determining free fatty acid content (method Ca 5a-40), iodine value (method $\mathrm{Cd}$ $1 \mathrm{~b}-87$ ) and peroxide value (method $\mathrm{Cd} 8-53$ ). Specific extinctions (method $\mathrm{p} 2.15$ ) and $p$-Anisidine value (method p2.4) of the samples were measured by using a Jenway 6305 Spectrophotometer (Barloworld Scientific Ltd., UK) according to the PORIM (1995) test methods.

\section{VISCOSITY MEASUREMENT}

A Brookfield LVDV-II+P viscometer (Brookfield Engineering Laboratories Inc., Middleboro, USA) was used to determine viscosity of the oil samples. $1 \mathrm{~mL}$ of oil was placed on the plate of the viscometer with spindle S-42; the viscosity of the sample was read in $\mathrm{cP}$ (centipoises) directly from the viscometer. The sample was equilibrated at $40^{\circ} \mathrm{C}$ before the measurement took place.

\section{POLAR COMPOUNDS}

The total polar compound contents were evaluated by the mini column method (Dobarganes et al. 2000). Briefly, about $1.0 \mathrm{~g}$ of oil was added to a mixture of light petroleum ether/diethyl ether $(90: 10, \mathrm{v} / \mathrm{v})$ and made up to $10 \mathrm{~mL}$ with the same solvent mixture. $5 \mathrm{~mL}$ of the solution were put on to a silica gel (Merck grade 60, 70-230 mesh) column. The nonpolar fraction was eluted with $60 \mathrm{~mL}$ of light petroleum ether/diethyl ether (90:10, v/v) while the polar fraction was eluted with $50 \mathrm{~mL}$ of diethyl ether. The solvent was removed by rotary evaporator; afterwards the flask was flushed under a stream of nitrogen for complete dryness. The completeness of fractionation was evaluated by analytical thin-layer chromatography in the elution system light petroleum ether: diethyl ether: acetic acid (70:40:1; v:v:v).

\section{FATTY ACIDS COMPOSITION}

Fatty acids of the oil samples were transesterified into their corresponding methyl esters following PORIM
(1995) test method p3.4 prior to analysis by gas-liquid chromatography. Fatty acid composition was evaluated using an auto-system XL gas chromatograph (Perkin Elmer Incorporate, Massachusetts, USA) furnished with a SP-2340 (Supelco Inc., Bellefonte, PA, USA) fused silica capillary column $(60 \mathrm{~m} \times 0.25 \mathrm{~mm}$ i.d $\times 0.20 \mu \mathrm{m}$ film thickness $)$ and a flame ionization detector. The carrier gas was nitrogen at a flow rate of $20 \mathrm{~mL} / \mathrm{min}$. Initial oven temperature was set to $100^{\circ} \mathrm{C}$, raised to $170^{\circ} \mathrm{C}$ at $20^{\circ} \mathrm{C} / \mathrm{min}$, then programmed to $230^{\circ} \mathrm{C}$ at $10^{\circ} \mathrm{C} / \mathrm{min}$, hold at $230^{\circ} \mathrm{C}$ for $7 \mathrm{~min}$ and finally heated to $250^{\circ} \mathrm{C}$ at $30^{\circ} \mathrm{C} / \mathrm{min}$. The detector and injector temperatures were both maintained at $250^{\circ} \mathrm{C}$. Methyl esters were quantified by comparing the retention times and peak area of the unknowns with known FAME standard mixtures.

\section{STATISTICAL ANALYSIS}

All data were reported as the mean and standard deviation (SD) and were subjected to one way analysis of variance (ANOVA). Mean values were compared at $p<0.05$ significant level by Duncan's multiple range test using SPSS 11.5 software package.

\section{RESULTS AND DISCUSSION}

Table 1 shows the percentage yield and antioxidant activity of PLE in different solvent systems. Highest yield $(16.02 \%)$ was obtained from $80 \%$ methanol extract while the minimum $(10.96 \%)$ from ethanol extract. Methanol is usually recommended for extraction of antioxidant compounds (Iqbal et al. 2005). Anwar et al. (2010) obtained the highest yield in barley seed extract with $80 \%$ methanol. As shown in Table 1, the highest amounts of total phenolics (TP) were extracted with $80 \%$ methanol $(1845.50 \mathrm{mg} / \mathrm{g})$ and the lowest with absolute ethanol $(1088.90 \mathrm{mg} / \mathrm{g})$. Iqbal et al. (2005) reported that the measurement of TP is a good measure of the antioxidant efficacy of the extracts. The results of antioxidant activity inlinoleic acid peroxidation system in terms of the measurement of inhibition of peroxidation indicated that $80 \%$ methanolic PLE displayed significantly higher $(p<0.05)$ inhibition $(82.21 \%)$ of peroxidation in linoleic acid compared with that of other two solvent systems, being lower than BHA $(92.07 \%)$. The per cent inhibition of peroxidation as shown by different solvent extracts of pandan leaf might

TABLE 1. Yield, total phenolic content and antioxidant activity in linoleic acid system of pandan leaf extracts

\begin{tabular}{lccc}
\hline Extract/Standard & Yield $(\%)$ & $\begin{array}{c}\text { Total phenolic contents } \\
(\text { mg GAE/100 g extract })\end{array}$ & $\begin{array}{c}\text { \% Inhibition of linoleic } \\
\text { acid oxidation }\end{array}$ \\
\hline BHA & nd & nd & $92.07 \pm 0.15^{\mathrm{d}}$ \\
$80 \%$ Methanol in water & $16.02 \pm 0.35^{\mathrm{c}}$ & $1845.50 \pm 0.40^{\mathrm{c}}$ & $82.21 \pm 0.42^{\mathrm{c}}$ \\
Methanol & $13.13 \pm 0.27^{\mathrm{b}}$ & $1234.10 \pm 0.21^{\mathrm{b}}$ & $76.06 \pm 0.45^{\mathrm{b}}$ \\
Ethanol & $10.96 \pm 0.23^{\mathrm{a}}$ & $1088.90 \pm 0.25^{\mathrm{a}}$ & $62.09 \pm 0.43^{\mathrm{a}}$ \\
\hline
\end{tabular}

Each value in the table represents the mean of three replicates \pm SD.

Values within a column with the same letters are not significantly different at $p<0.05$.

nd, not detectable 
be attributed to the presence of various polyphenolics. These results were in agreement with the findings of Velioglu et al. (1998) who reported that extracts with higher TP also exhibited strong activity against linoleic acid peroxidation. In the present study, we also determined the free radical scavenging capacity of pandan leaf extracts that increased in a concentration dependent manner (Table 2). In the present analysis, DPPH radical scavenging capacity varied significantly $(p<0.05)$ with respect to the extracting solvents used and $80 \%$ methanol extract, having higher TP also showed greater DPPH radicals cavenging capacity (60.62-89.87\%). The present results showed that the antioxidant activity of polar solvent extracts was significantly higher $(p<0.05)$ compared with those of less polar solvent extracts. Therefore, $80 \%$ methanol extract exhibited the highest yield and highest antioxidant activity, was used as effective antioxidant against the oxidation of SFO under microwave heating in the present work.

In all samples, the maximum amounts of hydroperoxides were observed at $16 \mathrm{~min}$ of microwave heating, decreasing thereafter (Table 3 ). Such observation was previously verified by Malheiro et al. (2012) when virgin olive oil was submitted to microwave heating. Being unstable primary oxidation products, the hydroperoxides are usually converted to secondary oxidation products (Laguerre et al. 2007). The control sample SFO had the higher level of PV compared to PLE treated samples $\left(\mathrm{SFP}_{1}, \mathrm{SFP}_{2}\right.$ and $\left.\mathrm{SFP}_{4}\right)$ at all corresponding heating time, indicating a higher extent of primary oxidation in SFO. A slow raise in PV of the treated samples as compared with that of the control clearly showed the antioxidant capacity of the PLE. Based on the PV, the order of stability of oil samples was as follow: $\mathrm{SFB}>\mathrm{SFP}_{4}>\mathrm{SFP}_{2}>\mathrm{SFP}_{1}>\mathrm{SFO}$ indicating that PLE was able to retard peroxide formation reaction. The para-anisidine values ( $p$-AV) generally reflect the amount of aldehydic secondary oxidation products in oils (Al-Kahtani 1991). The $p$-AV in all the oil samples increased significantly $(p<0.05)$ with microwave heating time and the change in $p$-AV of SFO (control sample) was found to be significantly higher $(p<0.05)$, with the lowest value obtained in SFB (Table 3 ). This confirms the results of the PV that showed the SFO to be more susceptible to

TABLE 2. DPPH radical scavenging activity (\%) of pandan leaf extracts

\begin{tabular}{ccccc}
\hline $\begin{array}{c}\text { Extract concentration } \\
(\mathrm{ppm})\end{array}$ & BHA & $80 \%$ methanol in water & Methanol & Ethanol \\
\hline 500 & $93.97 \pm 0.30^{\mathrm{dA}}$ & $60.62 \pm 0.15^{\mathrm{cA}}$ & $48.60 \pm 0.13^{\mathrm{bA}}$ & $39.04 \pm 0.27^{\mathrm{aA}}$ \\
1000 & $94.23 \pm 0.38^{\mathrm{dA}}$ & $84.57 \pm 0.35^{\mathrm{cB}}$ & $61.54 \pm 0.34^{\mathrm{bB}}$ & $57.58 \pm 0.56^{\mathrm{aB}}$ \\
1500 & $96.24 \pm 0.32^{\mathrm{dB}}$ & $89.87 \pm 0.40^{\mathrm{cC}}$ & $82.33 \pm 0.49^{\mathrm{bC}}$ & $73.67 \pm 0.48^{\mathrm{aC}}$ \\
\hline
\end{tabular}

Each value in the table represents the mean of three replicates $\pm \mathrm{SD}$.

Values within a row with the same lowercase letters are not significantly different at $p<0.05$.

Values within a column with the same uppercase letters are not significantly different at $p<0.05$

TABLE 3. Peroxide value, $p$-anisidine value and TOTOX value of sunflower oils during microwave heating

\begin{tabular}{|c|c|c|c|c|c|c|}
\hline \multirow[t]{2}{*}{ Parameter } & \multirow{2}{*}{$\begin{array}{l}\text { Heating time } \\
(\min )\end{array}$} & \multicolumn{5}{|c|}{ Oil samples* } \\
\hline & & SFO & SFB & $\mathrm{SFP}_{1}$ & $\mathrm{SFP}_{2}$ & $\mathrm{SFP}_{4}$ \\
\hline \multirow{5}{*}{$\begin{array}{l}\text { Peroxide } \\
\text { value } \\
\text { (meq per kg } \\
\text { of oil) }\end{array}$} & 0 & $3.31 \pm 0.02^{\mathrm{aA}}$ & $3.30 \pm 0.03^{\mathrm{aA}}$ & $3.31 \pm 0.02^{\mathrm{aA}}$ & $3.31 \pm 0.02^{\mathrm{aA}}$ & $3.31 \pm 0.02^{\mathrm{aA}}$ \\
\hline & 4 & $3.87 \pm 0.10^{\mathrm{cB}}$ & $3.44 \pm 0.30^{\mathrm{aA}}$ & $3.75 \pm 0.06^{\mathrm{bcB}}$ & $3.62 \pm 0.09^{\mathrm{abcA}}$ & $3.53 \pm 0.07^{\mathrm{abB}}$ \\
\hline & 8 & $6.58 \pm 0.12^{\mathrm{dC}}$ & $4.92 \pm 0.07^{\mathrm{aB}}$ & $5.67 \pm 0.17^{\mathrm{bcC}}$ & $5.53 \pm 0.16^{\mathrm{cB}}$ & $5.21 \pm 0.11^{\mathrm{abC}}$ \\
\hline & 16 & $13.40 \pm 0.11^{\mathrm{cE}}$ & $11.84 \pm 0.20^{\mathrm{aD}}$ & $12.63 \pm 0.14^{\mathrm{bE}}$ & $12.59 \pm 0.12^{\mathrm{bD}}$ & $12.11 \pm 0.15^{\mathrm{aE}}$ \\
\hline & 24 & $9.90 \pm 0.02^{\mathrm{eD}}$ & $8.33 \pm 0.12^{\mathrm{aC}}$ & $9.53 \pm 0.20^{\mathrm{dD}}$ & $9.21 \pm 0.11^{\mathrm{cC}}$ & $8.74 \pm 0.04^{\mathrm{bD}}$ \\
\hline \multirow{5}{*}{$\begin{array}{l}p \text {-Anisidine } \\
\text { value }\end{array}$} & 0 & $2.64 \pm 0.02^{\mathrm{aA}}$ & $2.62 \pm 0.01^{\mathrm{aA}}$ & $2.63 \pm 0.00^{\mathrm{aA}}$ & $2.62 \pm 0.01^{\mathrm{aA}}$ & $2.62 \pm 0.02^{\mathrm{aA}}$ \\
\hline & 4 & $4.54 \pm 0.06^{\mathrm{cB}}$ & $4.11 \pm 0.24^{\mathrm{aB}}$ & $4.45 \pm 0.06^{\mathrm{bcB}}$ & $4.36 \pm 0.06^{\mathrm{bcB}}$ & $4.24 \pm 0.08^{\mathrm{abB}}$ \\
\hline & 8 & $7.98 \pm 0.26^{\mathrm{cC}}$ & $5.93 \pm 0.08^{\mathrm{aC}}$ & $7.21 \pm 0.24^{\mathrm{bC}}$ & $6.93 \pm 0.13^{\mathrm{bC}}$ & $6.27 \pm 0.18^{\mathrm{aC}}$ \\
\hline & 16 & $12.73 \pm 0.63^{\mathrm{cD}}$ & $10.12 \pm 0.61^{\mathrm{aD}}$ & $12.56 \pm 0.36^{\mathrm{cD}}$ & $11.99 \pm 0.10^{\mathrm{cD}}$ & $11.08 \pm 0.35^{\mathrm{bD}}$ \\
\hline & 24 & $20.49 \pm 0.15^{\mathrm{eE}}$ & $15.77 \pm 0.46^{\mathrm{aE}}$ & $19.00 \pm 0.15^{\mathrm{dE}}$ & $18.11 \pm 0.27^{\mathrm{cE}}$ & $16.67 \pm 0.47^{\mathrm{bE}}$ \\
\hline \multirow{5}{*}{ TOTOX value } & 0 & $9.26 \pm 0.05^{\mathrm{aA}}$ & $9.22 \pm 0.07^{\mathrm{aA}}$ & $9.24 \pm 0.05^{\mathrm{aA}}$ & $9.26 \pm 0.05^{\mathrm{aA}}$ & $9.24 \pm 0.03^{\mathrm{aA}}$ \\
\hline & 4 & $12.28 \pm 0.26^{\mathrm{aB}}$ & $10.99 \pm 0.65^{\mathrm{aB}}$ & $11.95 \pm 0.18^{\mathrm{aB}}$ & $11.60 \pm 0.24^{\mathrm{aB}}$ & $11.30 \pm 0.16^{\mathrm{aB}}$ \\
\hline & 8 & $21.14 \pm 0.44^{\mathrm{dC}}$ & $15.77 \pm 0.19^{\mathrm{aC}}$ & $18.55 \pm 0.58^{\mathrm{cC}}$ & $17.99 \pm 0.08^{\mathrm{cC}}$ & $16.69 \pm 0.04^{\mathrm{bC}}$ \\
\hline & 16 & $39.53 \pm 0.67^{\mathrm{dD}}$ & $33.80 \pm 0.77^{\mathrm{aE}}$ & $37.82 \pm 0.21^{\mathrm{cD}}$ & $37.17 \pm 0.23^{\mathrm{cE}}$ & $35.30 \pm 0.63^{\mathrm{bE}}$ \\
\hline & 24 & $40.29 \pm 0.19^{\mathrm{eE}}$ & $32.43 \pm 0.63^{\mathrm{aD}}$ & $38.06 \pm 0.95^{\mathrm{dD}}$ & $36.53 \pm 0.17^{\mathrm{cD}}$ & $34.15 \pm 0.45^{\mathrm{bD}}$ \\
\hline
\end{tabular}

* Sunflower oil containing $0.1 \%$ leaf extract ( $\left.\mathrm{SFP}_{1}\right)$; sunflower oil containing $0.2 \%$ leaf extract $\left(\mathrm{SFP}_{2}\right)$; sunflower oil containing $0.4 \%$ leaf extract $\left(\mathrm{SFP}_{4}\right)$; sunflower oil containing $0.02 \%$ BHA (SFB) and sunflower oil without any additive (SFO).

Each value in the table represents the mean of three replicates $\pm \mathrm{SD}$; values within a row with the same lowercase letters are not significantly different at $p<0.05$; values within a column with the same uppercase letters are not significantly different at $p<0.05$ 
oxidation at high temperature than the samples treated with PLE. The $p$-AVs were in the range of 15.77-19.00 for PLE treated samples and 20.49 for control sample after 24 min of microwave heating. It can be seen that adding PLE to SFO slowed down the rate of formation of secondary oxidation products in SFO. Bushra et al. (2007) reported that corncob extract was found to be effective in retarding the formation of carbonyl components in corn oil which predicted its high antioxidant potential. $p-\mathrm{AV}$ is often used in the industry in conjunction with PV to calculate the so-called total oxidation or TOTOX value given as: TOTOX $=2 \mathrm{PV}+p-\mathrm{AV}$ (Shahidi \& Wanasundara 2002). During microwave heating TOTOX values increased significantly $(p<0.05)$ with times and after the end of 24 min heating, the TOTOX values were found to be highest in SFO (40.29) and lowest in SFB (32.43) (Table 3). The lower TOTOX values of the treated samples indicated more stable to oxidative rancidity than the control. In the present study, the PV and $p$-AV were significantly reduced by the extract in a dose dependent manner with the optimum concentration at

TABLE 4. Free fatty acid and specific extinctions of sunflower oils during microwave heating

\begin{tabular}{|c|c|c|c|c|c|c|}
\hline \multirow[t]{2}{*}{ Parameter } & \multirow{2}{*}{$\begin{array}{l}\text { Heating } \\
\text { time (min) }\end{array}$} & \multicolumn{5}{|c|}{ Oil samples* } \\
\hline & & SFO & SFB & $\mathrm{SFP}_{1}$ & $\mathrm{SFP}_{2}$ & $\mathrm{SFP}_{4}$ \\
\hline \multirow[t]{5}{*}{ Free fatty acid (\%) } & 0 & $0.16 \pm 0.00^{\mathrm{aA}}$ & $0.15 \pm 0.01^{\mathrm{aA}}$ & $0.16 \pm 0.01^{\mathrm{aA}}$ & $0.16 \pm 0.01^{\mathrm{aA}}$ & $0.16 \pm 0.01^{\mathrm{aA}}$ \\
\hline & 4 & $0.16 \pm 0.03^{\mathrm{aA}}$ & $0.15 \pm 0.01^{\mathrm{aA}}$ & $0.16 \pm 0.00^{\mathrm{aA}}$ & $0.16 \pm 0.00^{\mathrm{aA}}$ & $0.16 \pm 0.03^{\mathrm{aA}}$ \\
\hline & 8 & $0.19 \pm 0.03^{\mathrm{aAB}}$ & $0.15 \pm 0.01^{\mathrm{aA}}$ & $0.18 \pm 0.02^{\mathrm{aAB}}$ & $0.17 \pm 0.02^{\mathrm{aA}}$ & $0.16 \pm 0.03^{\mathrm{aA}}$ \\
\hline & 16 & $0.22 \pm 0.00^{\mathrm{bBC}}$ & $0.17 \pm 0.02^{\mathrm{aA}}$ & $0.21 \pm 0.01^{\mathrm{bB}}$ & $0.21 \pm 0.01^{\mathrm{bB}}$ & $0.20 \pm 0.02^{\mathrm{bB}}$ \\
\hline & 24 & $0.23 \pm 0.02^{\mathrm{bC}}$ & $0.19 \pm 0.02^{\mathrm{aB}}$ & $0.20 \pm 0.02^{\mathrm{aB}}$ & $0.20 \pm 0.03^{\mathrm{aAB}}$ & $0.20 \pm 0.02^{\mathrm{aB}}$ \\
\hline \multirow[t]{5}{*}{$\mathrm{E}^{1 \%}{ }_{1 \mathrm{~cm}}$ at $233 \mathrm{~nm}$} & 0 & $1.25 \pm 0.01^{\mathrm{aA}}$ & $1.24 \pm 0.01^{\mathrm{aA}}$ & $1.24 \pm 0.01^{\mathrm{aA}}$ & $1.24 \pm 0.02^{\mathrm{aA}}$ & $1.24 \pm 0.01^{\mathrm{aA}}$ \\
\hline & 4 & $1.81 \pm 0.09^{\mathrm{bB}}$ & $1.39 \pm 0.14^{\mathrm{aA}}$ & $1.73 \pm 0.06^{\mathrm{bB}}$ & $1.65 \pm 0.13^{\text {ьв }}$ & $1.41 \pm 0.11^{\mathrm{aA}}$ \\
\hline & 8 & $2.39 \pm 0.12^{\mathrm{cC}}$ & $1.86 \pm 0.12^{\mathrm{aB}}$ & $2.27 \pm 0.12^{\mathrm{cC}}$ & $2.06 \pm 0.13^{\mathrm{bC}}$ & $1.92 \pm 0.08^{\mathrm{abB}}$ \\
\hline & 16 & $3.23 \pm 0.10^{\mathrm{bD}}$ & $2.75 \pm 0.12^{\mathrm{aC}}$ & $3.11 \pm 0.16^{\mathrm{bD}}$ & $2.90 \pm 0.04^{\mathrm{aD}}$ & $2.84 \pm 0.17^{\mathrm{aC}}$ \\
\hline & 24 & $4.37 \pm 0.06^{\mathrm{cE}}$ & $3.61 \pm 0.12^{\mathrm{aD}}$ & $4.16 \pm 0.07^{\mathrm{cE}}$ & $3.84 \pm 0.18^{\mathrm{bE}}$ & $3.73 \pm 0.11^{\mathrm{abD}}$ \\
\hline \multirow{5}{*}{$\mathrm{E}^{1 \%}{ }_{1 \mathrm{~cm}}$ at $269 \mathrm{~nm}$} & 0 & $0.48 \pm 0.01^{\mathrm{aA}}$ & $0.47 \pm 0.02^{\mathrm{aA}}$ & $0.48 \pm 0.01^{\mathrm{aA}}$ & $0.48 \pm 0.01^{\mathrm{aA}}$ & $0.48 \pm 0.01^{\mathrm{aA}}$ \\
\hline & 4 & $0.96 \pm 0.07^{\mathrm{cв}}$ & $0.70 \pm 0.08^{\mathrm{aB}}$ & $0.91 \pm 0.08^{\mathrm{abcB}}$ & $0.87 \pm 0.11^{\mathrm{abcB}}$ & $0.78 \pm 0.10^{\mathrm{abB}}$ \\
\hline & 8 & $1.39 \pm 0.13^{\mathrm{dC}}$ & $0.95 \pm 0.07^{\mathrm{aC}}$ & $1.29 \pm 0.10^{\mathrm{cdC}}$ & $1.16 \pm 0.11^{\mathrm{bcC}}$ & $1.09 \pm 0.08^{\mathrm{abC}}$ \\
\hline & 16 & $1.64 \pm 0.10^{\mathrm{cD}}$ & $1.22 \pm 0.06^{\mathrm{aD}}$ & $1.57 \pm 0.12^{\mathrm{bcD}}$ & $1.45 \pm 0.12^{\mathrm{bcD}}$ & $1.38 \pm 0.11^{\mathrm{abD}}$ \\
\hline & 24 & $1.92 \pm 0.08^{\mathrm{cE}}$ & $1.53 \pm 0.13^{\mathrm{aE}}$ & $1.86 \pm 0.15^{\mathrm{cE}}$ & $1.77 \pm 0.06^{\mathrm{bcE}}$ & $1.63 \pm 0.15^{\mathrm{abE}}$ \\
\hline
\end{tabular}

*Sunflower oil containing $0.1 \%$ leaf extract $\left(\mathrm{SFP}_{1}\right)$; sunflower oil containing $0.2 \%$ leaf extract $\left(\mathrm{SFP}_{2}\right)$; sunflower oil containing $0.4 \%$ leaf extract $\left(\mathrm{SFP}_{4}\right)$; sunflower oil containing $0.02 \%$ BHA (SFB) and sunflower oil without any additive (SFO).

Each value in the table represents the mean of three replicates $\pm \mathrm{SD}$; values within a row with the same lowercase letters are not significantly different at $p<0.05$; values within a column with the same uppercase letters are not significantly different at $p<0.05$

TABLE 5. Iodine value, viscosity and total polar compound of sunflower oils during microwave heating

\begin{tabular}{|c|c|c|c|c|c|c|}
\hline \multirow[t]{2}{*}{ Parameter } & \multirow{2}{*}{$\begin{array}{l}\text { Heating } \\
\text { Time (min) }\end{array}$} & \multicolumn{5}{|c|}{ Oil samples* } \\
\hline & & SFO & SFB & $\mathrm{SFP}_{1}$ & $\mathrm{SFP}_{2}$ & $\mathrm{SFP}_{4}$ \\
\hline \multirow[t]{5}{*}{ Iodine value } & 0 & $136.15 \pm 0.13^{\mathrm{aE}}$ & $136.15 \pm 0.13^{\mathrm{aD}}$ & $136.15 \pm 0.17^{\mathrm{aE}}$ & $136.15 \pm 0.18^{\mathrm{aE}}$ & $136.15 \pm 0.13^{\mathrm{aE}}$ \\
\hline & 4 & $133.54 \pm 0.38^{\mathrm{aD}}$ & $134.95 \pm 0.45^{\mathrm{cC}}$ & $134.44 \pm 0.47^{\mathrm{bcD}}$ & $133.92 \pm 0.42^{\mathrm{abD}}$ & $134.55 \pm 0.36^{\mathrm{bcD}}$ \\
\hline & 8 & $132.78 \pm 0.35^{\mathrm{aC}}$ & $134.08 \pm 0.55^{\mathrm{cB}}$ & $133.69 \pm 0.18^{\mathrm{bcC}}$ & $133.11 \pm 0.18^{\mathrm{abC}}$ & $133.83 \pm 0.48^{\mathrm{bcC}}$ \\
\hline & 16 & $131.90 \pm 0.30^{\mathrm{aB}}$ & $133.78 \pm 0.35^{\mathrm{cB}}$ & $132.45 \pm 0.52^{\mathrm{abB}}$ & $132.19 \pm 0.22^{\mathrm{abB}}$ & $132.85 \pm 0.49^{\mathrm{bB}}$ \\
\hline & 24 & $126.62 \pm 0.40^{\mathrm{aA}}$ & $132.15 \pm 0.16^{\mathrm{cA}}$ & $130.84 \pm 0.51^{\mathrm{bA}}$ & $130.77 \pm 0.28^{\mathrm{bA}}$ & $131.85 \pm 0.19^{\mathrm{cA}}$ \\
\hline \multirow[t]{5}{*}{ Viscosity (cP) } & 0 & $28.16 \pm 0.19^{\mathrm{aA}}$ & $28.12 \pm 0.17^{\mathrm{aA}}$ & $28.14 \pm 0.19^{\mathrm{aA}}$ & $28.13 \pm 0.19^{\mathrm{aA}}$ & $28.13 \pm 0.18^{\mathrm{aA}}$ \\
\hline & 4 & $32.49 \pm 0.39^{\mathrm{bB}}$ & $31.65 \pm 0.18^{\mathrm{aB}}$ & $32.45 \pm 0.48^{\mathrm{bB}}$ & $32.37 \pm 0.12^{\mathrm{bB}}$ & $31.75 \pm 0.09^{\mathrm{aB}}$ \\
\hline & 8 & $32.61 \pm 0.18^{\mathrm{aB}}$ & $32.09 \pm 0.37^{\mathrm{aC}}$ & $32.31 \pm 0.18^{\mathrm{aB}}$ & $32.21 \pm 0.22^{\mathrm{aB}}$ & $32.11 \pm 0.09^{\mathrm{aC}}$ \\
\hline & 16 & $32.93 \pm 0.33^{\mathrm{aB}}$ & $32.47 \pm 0.15^{\mathrm{aC}}$ & $32.73 \pm 0.18^{\mathrm{aB}}$ & $32.61 \pm 0.28^{\mathrm{aB}}$ & $32.50 \pm 0.50^{\mathrm{aC}}$ \\
\hline & 24 & $33.23 \pm 0.27^{\mathrm{bC}}$ & $32.59 \pm 0.21^{\mathrm{aC}}$ & $32.99 \pm 0.26^{\mathrm{abC}}$ & $32.83 \pm 0.33^{\mathrm{abB}}$ & $32.69 \pm 0.47^{\mathrm{abC}}$ \\
\hline \multirow{5}{*}{$\begin{array}{l}\text { Total polar } \\
\text { compound (\%) }\end{array}$} & 0 & $3.41 \pm 0.02^{\mathrm{aA}}$ & $3.41 \pm 0.01^{\mathrm{aA}}$ & $3.41 \pm 0.01^{\mathrm{aA}}$ & $3.41 \pm 0.02^{\mathrm{aA}}$ & $3.41 \pm 0.04^{\mathrm{aA}}$ \\
\hline & 4 & $4.91 \pm 0.06^{\mathrm{cB}}$ & $4.46 \pm 0.19^{\mathrm{aB}}$ & $4.80 \pm 0.07^{\mathrm{bcB}}$ & $4.64 \pm 0.05^{\mathrm{abB}}$ & $4.55 \pm 0.16^{\mathrm{aB}}$ \\
\hline & 8 & $7.88 \pm 0.12^{\mathrm{bC}}$ & $7.36 \pm 0.23^{\mathrm{aC}}$ & $7.69 \pm 0.26^{\mathrm{abc}}$ & $7.51 \pm 0.11^{\mathrm{aC}}$ & $7.42 \pm 0.10^{\mathrm{aC}}$ \\
\hline & 16 & $10.44 \pm 0.08^{\mathrm{cD}}$ & $9.22 \pm 0.25^{\mathrm{aD}}$ & $10.26 \pm 0.13^{\mathrm{cD}}$ & $9.78 \pm 0.17^{\mathrm{bD}}$ & $9.49 \pm 0.17^{\mathrm{abD}}$ \\
\hline & 24 & $14.27 \pm 0.05^{\mathrm{dE}}$ & $12.66 \pm 0.03^{\mathrm{aE}}$ & $13.08 \pm 0.13^{\mathrm{cE}}$ & $12.85 \pm 0.12^{\mathrm{bE}}$ & $12.72 \pm 0.08^{\mathrm{abE}}$ \\
\hline
\end{tabular}

*Sunflower oil containing $0.1 \%$ leaf extract $\left(\mathrm{SFP}_{1}\right)$; sunflower oil containing $0.2 \%$ leaf extract $\left(\mathrm{SFP}_{2}\right)$; sunflower oil containing $0.4 \%$ leaf extract $\left(\mathrm{SFP}_{4}\right)$; sunflower oil containing $0.02 \%$ BHA (SFB) and sunflower oil without any additive (SFO).

Each value in the table represents the mean of three replicates $\pm \mathrm{SD}$; values within a row with the same lowercase letters are not significantly different at $P<0.05$; values within a column with the same uppercase letters are not significantly different at $P<0.05$ 


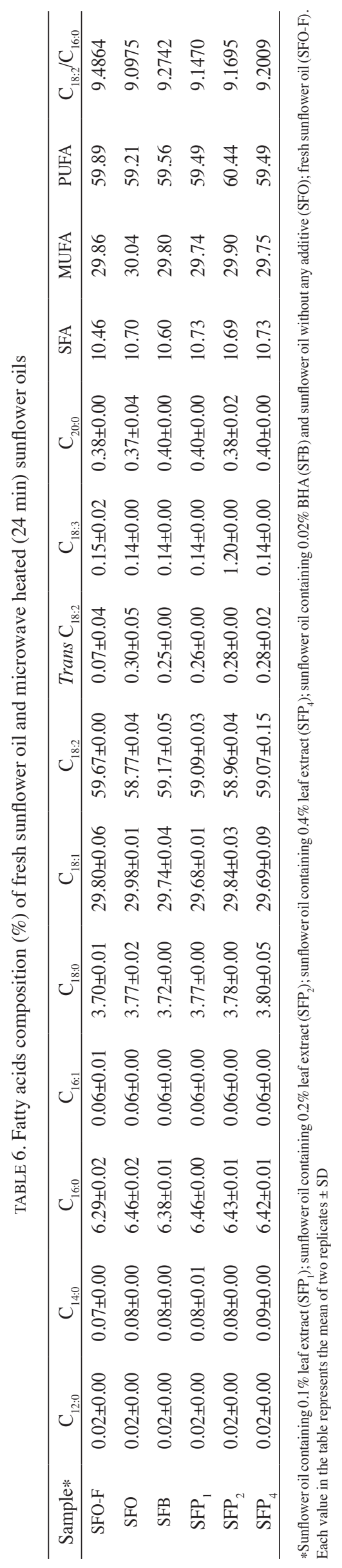


$0.4 \%$. But PLE was not better than BHA in lowering the PV and $p$-AV during microwave heating. Zia-ur-Rehman et al. (2003) reported the antioxidant activity of ginger extracts in stabilizing sunflower oil under accelerated storage conditions in a concentration dependent manner.

Interestingly, accumulation of free fatty acid (FFA) was not significantly affected $(p<0.05)$ by extract concentration within the extract range studied (Table 4). Malheiro et al. (2012) did not observe any significant changes in FFA in the olive oil samples with or without tea extracts during microwave heating. At the end of heating, the amount of FFA was found to be slightly lower in SFB $(0.19 \%)$ or treated samples $(0.20 \%)$ as compared with control sample SFO $(0.23 \%)$. However, in this study, addition of PLE to SFO decreased FFA level of SFO, but not significantly enough and the highest FFA figure found in SFO at the end of 24 min heating is still far below the accepted limit of $2 \%$ (Matthaus 2006). Ultraviolet absorptions at 233 and $269 \mathrm{~nm}\left(\mathrm{E}^{1 \%}{ }_{233}\right.$ and $\left.\mathrm{E}^{1 \%}{ }_{269}\right)$ for all the samples increased significantly $(p<0.05)$ throughout the heating periods (Table 4). The levels of conjugated dienes and trienes at the end of heating were however highest in control SFO, with lowest level found in SFB. The lower levels of both conjugated dienes and trienes found in the samples treated with PLE are indications of good oxidative stability compared to control and it is because of the antioxidant effect of PLE. However, PLE addition to the SFO decelerated conjugated dienes and trienes formation in SFO and better performance was indicated in $0.4 \%$ leaf extract compared with 0.1 or $0.2 \%$ extract. Bushra et al. (2007) reported that corn oil samples stabilized with corncob extract showed lower levels of specific extinctions at 232 and $268 \mathrm{~nm}$ compared with control, indicating antioxidant potential of the corncob extracted components.

During heating, a progressive decrease in unsaturation was observed in oil samples by the determination of iodine value (IV) andthe highest significant $(p<0.05)$ change in the IV was shown by the control sample SFO, thus indicating that the highest decrease in double bonds occurred due to oxidative rancidity in that sample (Table 5). The present results showed that adding PLE to SFO led to the reduction in the decreasing rate of the IV of SFO. The viscosities of sunflower oils were significantly increased $(p<0.05)$ initially (up to $4 \mathrm{~min}$ ); afterwards increments were not significant (Table 5). At the end of heating, the sample containing $0.1 \%$ extract $\left(\mathrm{SFP}_{1}\right.$ ) exhibited the highest value $(32.99 \mathrm{cP})$ for viscosity compared to other PLE containing oils, showing the least antioxidant efficacy towards preventing the oxidation of SFO. A regular increase in total polar compound (TPC) was observed for all the samples throughout the heating period (Table 5). TPC value was in the range $12.75-13.08 \%$ for the samples containing PLE after 24 min heating, while maximum value for control sample was $14.27 \%$. In the present work, highest IV, viscosity and TPC were observed for control sample followed by $\mathrm{SFP}_{1}, \mathrm{SFP}_{2}, \mathrm{SFP}_{4}$ and $\mathrm{SFB}$, respectively. Fatty acid composition of fresh sunflower oil (SFO-F) and 24 min microwave heated sunflower oils are given in Table
6. The primary fatty acids of fresh sample were linoleic $(59.67 \%)$ and oleic $(29.80 \%)$ acids while palmitic $(6.29 \%)$ and stearic $(3.70 \%)$ were present in minor quantities. As shown in Table 6, the amount of $\mathrm{C}_{18: 2}$ was slightly lower in control sample SFO as compared with the four other samples heated for $24 \mathrm{~min}$, showing the oxidation of unsaturated fatty acid into primary and secondary oxidation products. The value of the $\mathrm{C}_{18: 2} / \mathrm{C}_{16: 0}$ ratios were low in the SFO as compared to the other samples as a result of adding antioxidant. Microwave heating caused little variations in the fatty acid composition of the tested samples and after 24 min of heating, all samples did not produce a significant effect on the $\mathrm{C}_{18: 2} / \mathrm{C}_{16: 0}$ ratio.

\section{CONCLUSION}

Pandan leaf extract displayed good antioxidant. The present study provides an insight into understanding the behavior of added natural antioxidants on sunflower oil oxidation. By combining the knowledge of different antioxidant assays and assessment of oxidation parameters in the present study, it can be asserted that addition of pandan leaf slowed down the oxidative deterioration of oil by improving its hydrolytic stability, inhibiting double bond conjugation and reducing the losses of polyunsaturated fatty acids. This study suggested that pandan leaf may be explored as a viable source of potent natural antioxidants for the protection of vegetable oils from oxidation and for the exploitation in the food and nutraceutical industries. An assessment of the toxicity and kinetic studies, as well as the function of these extracts in food and biological systems needs to be investigated.

\section{REFERENCES}

Al-Kahtani, H. 1991. Survey of quality of used frying oils from restaurants. Journal of American Oil Chemists Society 68: 857-862.

Anwar, F., Qayyum, H.M.A., Abdullah Ijaz Hussain, A.L. \& Iqbal, S. 2010. Antioxidant activity of $100 \%$ and $80 \%$ methanol extracts from barley seeds (Hordeum vulgare L.): Stabilization of sunflower oil. Grasas Y Aceites 61: 237-243.

AOCS. 1987. Official Methods and Recommended Practices of the American Oil Chemists' Society. 4th ed. Champaign: AOCS press.

Bhattacharjee, P., Kshirsagar, A. \& Singhal, R.S. 2005. Supercritical carbon dioxide extraction of 2-cetyl-1-pyrroline from Pandanus amaryllifolius Roxb. Food Chemistry 91: 255-259.

Blois, M.S. 1958. Antioxidant determinations by the use of a stable free radical. Nature 181: 1199-1200.

Bushra, S., Farooq, A. \& Roman, P. 2007. Antioxidant potential of corncob extracts for stabilization of corn oil subjected to microwave heating. Food Chemistry 104: 997-1005.

Che Man, Y.B. \& Tan, C.P. 1999. Effects of natural and synthetic antioxidants on changes in refined, bleached, and deodorized palm olein during deep-fat frying of potato chips. Journal of American Oil Chemists Society 76: 332-339.

Dobarganes, M.C., Velasco, J. \& Dieffenbacher, A. 2000. Determination of polar compounds, polymerized and 
oxidized triacylglycerols and diacylglycerols in oils and fats. Pure and Applied Chemistry 72: 1563-1575.

Huang, A.S., Hsieh, O.A.L., Huang, C.L. \& Chang, S.S. 1981. A comparison of the stability of sunflower oil and corn oil. Journal of American Oil Chemists Society 58: 997-1001.

Hussain, A.I., Anwar, F., Sherazi, S.T.H. \& Przybylski, R. 2008. Chemical composition, antioxidant and antimicrobial activities of basil (Ocimum basilicum) essential oils depends on seasonal variations. Food Chemistry 108: 986-995.

Iqbal, S., Bhanger, M.I. \& Anwar, F. 2005. Antioxidant properties and components of some commercially available varieties of rice bran in Pakistan. Food Chemistry 93: 265-272.

Jimtaisong, A. \& Krisdaphong, P. 2013. Antioxidant activity of Pandanus amaryllifolius leaf and root extract and its application in topical emulsion. Tropical Journal of Pharmaceutical Research 12: 425-431.

Kikuzaki, H. \& Nakatani, N. 1993. Antioxidant effects of some ginger constituents. Journal of Food Science 58: 1407-1410.

Labuza, T.P. 1971. Kinetics of lipid oxidation in foods. CRC Critical Reviews in Food Technology 2: 355-404.

Laguerre, M., Lecomte, J. \& Villeneuve, P. 2007. Evaluation of the ability of antioxidants to counteract lipid oxidation: Existing methods, new trends and challenges. Progress in Lipid Research 46: 244-282.

Lister, E. \& Wilson, P. 2001. Measurement of total phenolics and ABTS assay for antioxidant activity (personal communication). Lincoln, New Zealand: Crop Research Institute.

Malheiro, R., Casal, S., Lamas, H., Bento,A. \& Pereira, J.A. 2012. Can tea extracts protect extra virgin olive oil from oxidation during microwave heating? Food Research International 48: $148-154$.

Matthaus, B. 2006. Utilization of high-oleic rapeseed oil for deep fat frying of French fries compared to other commonly used edible oils. European Journal of Lipid Science and Technology 108: 200-211.

PORIM. 1995. PORIM Test Methods. Malaysia: Palm Oil Research Institute of Malaysia.

Ricardo, M., Nuno, R., Gabriel, M., Albino, B., José, A.P. \& Susana, C. 2013. The use of olive leaves and tea extracts as effective antioxidants against the oxidation of soybean oil under microwave heating. Industrial Crops and Products 44: 37-43.

Rodrigues, N., Malheiro, R., Casal, S., Manzanera, M.C.,Asensio, S., Bento,A. \& Pereira, J.A. 2012. Influence of spike lavender (Lavandula latifolia Med.) essential oil in the quality, stability and composition of soybean oil during microwave heating. Food and Chemical Toxicology 50: 2894-2901.
Shahidi, F. \& Wanasundara, U.N. 2002. Methods for measuring oxidative rancidity in fats and oils. In Food Lipids: Chemistry, Nutrition, and Biotechnology, edited by Akoh, C.C. \& Min, D.B. 2nd ed. New York: Marcel Dekker, Inc. pp. 465-482.

Velioglu, Y.S., Mazza, G., Gao, L. \& Oomah, B.D. 1998. Antioxidant activity and total phenolics in selected fruits, efetablesans grain products. Journal of Agriculture and Food Chemistry 46: 4113-4117.

Wakte, K.V., Thengane, R.J., Jawali, N. \& Nadaf, A.B. 2010. Optimization of HS-SPME conditions for quantification of 2-acetyl-1-pyrroline and study of other volatiles in Pandanus amaryllifolius Roxb. Food Chemistry 121: 595-600.

Wu, P.F. \& Nawar, W.W. 1986. A technique for monitoring the quality of used frying oils. Journal of American Oil Chemists Society 63: 1363-1367.

Yoshida, H., Tatsumi, M. \& Kajimoto, G. 1992. Influence of fatty acids on the tocopherol stability in vegetable oils during microwave heating. Journal of American Oil Chemists Society 69: 119-125.

Zia-Ur-Rehman, Salariya, A. \& Habib, F. 2003. Antioxidant activity of ginger extract in sunflower oil. Journal of the Science, Food and Agriculture 83: 624-629.

M. Abbas Ali*

Department of Chemistry

Faculty of Applied Science and Engineering

Rajshahi University of Engineering \& Technology

Rajshahi-6204

Bangladesh

Rafiqqah binti Mohamad Sabri, Khu Say Li \&

Nik Azmi Nik Mahmood

Department of Bioprocess Engineering

Faculty of Chemical Engineering

Universiti Teknologi Malaysia

81310 Skudai, Johor Darul Takzim

Malaysia

*Corresponding author; email: radwiya44@yahoo.com

Received: 31 August 2014

Accepted: 11 March 2015 